\title{
Pengembangan Modul Pendidikan Multikultural Berbasis Karakter Cinta Tanah Air dan Nasionalis pada Pembelajaran Tematik
}

\author{
Laila Fatmawati, Rani Dita Pratiwi, Vera Yuli Erviana \\ lailaokyfatmawati@gmail.com,ranidepe@gmail.com, vera.erviana@pgsd.uac.ac.id \\ PGSD FKIP Universitas Ahmad Dahlan
}

\section{The Development of Multicultural Education Modules Based on Patriotism and Nationalism Character on Thematic Learning}

\begin{abstract}
This research aims to describe the development steps and the appropriateness of multicultural education module based on the character of patriotism and nationalism in thematic learning for students in $2^{\text {nd }}$ grade Elementary School. This is a research and development applying Borg and Gall design. The trial was conducted on 10 students of $2^{\text {nd }}$ grade in Muhammadiyah Bodon Elementary School. The data collection techniques in this research were interviews, observations, module feasibility assessments by experts, teachers' assessment, and questionnaire of learners' responses. The eligibility of the multicultural education module is shown by the result of the assessment by the validation experts at the time of FGD. The validation by media expert scored of 72, the validation by learning expert scored of 74, and the validation by language expert scored of 60. The limited product trial were conducted in class II A, based on the students' assessment get the mean score of 37.5, while the assessment by the teacher scored 70 , both are very good category. The field trial were conducted in class II B, based on the students' score, obtained 36.94 score, and 76 from the teachers; both are very good category.
\end{abstract}

Keywords: multicultural education, character, patriotism, nationalism, integrative thematic

$\begin{array}{ccc}\text { Article Info } & \\ \text { Received date: } 30 \text { Oktober } 2017 & \text { Revised date: } 8 \text { Desember } 2017 \quad \text { Accepted date: } 19 \text { Desember } 2017\end{array}$

\section{PENDAHULUAN}

Indonesia adalah salah satu negara dengan tingkat pluralisme yang sangat tinggi. Hal ini ditunjukkan dengan heterogenitas ras, suku bangsa, adat istiadat, budaya, agama, dan strata sosial masyarakat. Data tahun 2010 Badan Pusat Statistik mencatat bahwa jumlah penduduk Indonesia menurut kelompok suku bangsa sebanyak 236.728.379. Etnis Jawa menduduki peringkat pertama dengan jumlah penduduk 95,2 juta (40,22\%), kemudian disusul oleh etnis Sunda 36,7 juta (15,5\%), Batak dengan jumlah penduduk 8,7 juta (3,58\%), Suku Sulawesi lainnya 7,6 juta (3,22\%), Madura berada di peringkat ke 5 dengan jumlah penduduk 7,2 juta $(3,03 \%)$ dan masih banyak lagi etnis di Indonesia (Na'im; Syahputra, 2010).

Paparan data di atas menggambarkan bahwa Indonesia sangat plural, kondisi ini merupakan suatu keniscayaan yang harus diterima keberadaannya oleh setiap masyarakat. Namun tidak adanya kemerataan menjadikan resiko terjadinya konflik cukup tinggi. Kesadaran masyarakat akan pluralisme dan nilai toleransi yang mulai luntur, sehingga membuat masyarakat begitu mudah tersulut konflik. Berdasarkan data Kementerian Sosial (Sumarno, 2010) jumlah konflik sosial di Indonesia tahun 2010 berjumlah 93 kasus, menurun pada tahun 2011 menjadi 77 kasus, dan tahun 2012 meningkat lagi menjadi 89 kasus, serta terdapat 189 titik rawan konflik sosial di Indonesia. 
Pada praktiknya masih banyak kasus mengenai lunturnya nasionalisme dan cinta tanah air di Indonesia. Sebagai contoh kasus kekerasan di Jawa Tengah meningkat dari tahun 2008 sampai 2012 dengan rata-rata kasus terjadi setiap bulan, atau 14 kasus setiap harinya. Hal ini menunjukan bahwa masyarakat mulai mengalami pergeseran nila-nilai nasionalisme karena mereka sekarang lebih memilih memecahkan masalah dengan menggunakan kekerasan dan kekuatan masa (Jakarta Pos, 2013).

Guna mencegah agar konflik tidak terulang lagi dan menimbulkan kerugian yang lebih besar, diperlukan penanganan dari akar permasalahannya yaitu menguatkan kembali karakter cinta tanah air dan nasionalisme melalui pendidikan multikultural di jenjang pendidikan formal. Pendidikan multikultural mengembangkan konsep toleransi, menghargai perbedaan, kecakapan belajar hidup bersama di tengah perbedaan. Senada dengan pendapat Musa Asya"rie (Tasrif, 2015) bahwa pendidikan multikultural bermakna sebagai proses pendidikan cara hidup menghormati, tulus, toleransi terhadap keragaman budaya yang hidup di tengah-tengah masyarakat plural sehingga peserta didik kelak memiliki kelenturan mental bangsa dalam menyikapi konflik sosial di masyarakat.

Hal mendasar yang urgen untuk diajarkan kepada peserta didik adalah memberikan pemahaman tentang keragaman sebagai modal pembangunan serta menerima keragaam sebagai suatu tidak dapat dielakkan. Pelaksanaan pendidikan multikultural sudah termuat dalam peraturan Undang-Undang No 20 Tahun 2003, Sistem Pendidikan Nasional, Pasal 4 dari ayat 1 hingga ayat 6 menunjukan multikulturalisme menjadi sebuah landasan bagi penyelenggaraan pendidikan di Indonesia. Oleh karena itu, menyelenggarakan pendidikan multikultural menjadi kewajiban sekolah, khususnya dimulai sejak jenjang SD.

Permasalahan yang masih terjadi adalah jarang sekali SD yang menerapkan pendidikan multikultural, dikarenakan ketidakpahaman dari guru dan civitas sekolah tentang pendidikan multikultural. Hasil penelitian (Hanum; Raharja, 2013) yang dilakukan di 25 SD di DIY menunjukkan bahwa sebagian besar guru, kepala sekolah, dan komite sekolah, belum mengetahui bahkan asing dengan istilah pendidikan multikultural.

Didukung oleh hasil studi pendahuluan melalui wawancara awal dengan beberapa guru di SD Muhammadiyah Bodon tentang penerapan pendidikan multikultural, diperoleh informasi bahwa selama ini guru belum mengintegrasikan pendidikan multikultural dalam pembelajaran tematik. Guru banyak yang belum memahami tentang esensi dari pendidikan multikultural. Pemahaman guru tentang pendidikan multikultural yang kurang menyebabkan guru tidak siap menyampaikan pesan pesan-pesan multikultural khususnya tentang karakter toleransi, cinta tanah air dan semangat kebangsaan. Selain itu penanaman karakter bangsa tentang nasionalisme dan cinta tanah air hanya dijelaskan dan diajarkan pada muatan pelajaran PPKn. Oleh karena itu penting sosialisasi tentang penanaman pendidikan multikultural kepada para pendidik agar mampu mengajarkan dan ditularkan kepada peserta didiknya.

Tidak hanya guru yang kurang memahami tentang pendidikan multikultural. Hasil wawancara dengan 10 peserta didik SD kelas 2 di SD Muhammadiyah Bodon menunjukkan bahwa semua peserta didik masih awan dengan istilah pendidikan multikultural. Ada beberapa peserta didik yang tidak mampu melafalkan multikultural dengan benar karena baru pertama kali mendengar istilah itu.

Padatnya materi yang harus dipelajari dalam implementasi pembelajaran tematikintegratif, sehingga menyebabkan guru khawatir menerapkan pendidikan multikultural dapat mengganggu waktu pembelajaran di kelas dan guru tidak dapat menyelesaikan materi sesuai dengan target waktu yang telah ditentukan. Selain itu selama ini belum pernah ada modul pendidikan multikultural yang dapat diintegrasikan dalam pembelajaran tematik integratif. Berdasarkan hasil need analysis di atas, dibutuhkan solusi berupa modul pendidikan multikultural di SD. 
Pengembangan Modul Pendidikan Multikultural Berbasis Karakter Cinta Tanah Air dan Nasionalis pada Pembelajaran Tematik (Laila Fatmawati, Rani Dita Pratiwi, Vera Yuli Erviana)

Tujuan yang ingin dicapai dari penelitian ini untuk mendeskripsikan langkah-langkah pengembangan modul serta kelayakan modul pendidikan multikultural berbasis karakter cinta tanah air dan nasionalisme dalam pembelajaran tematik-integratif. Dari tujuan penelitian yang telah dirumuskan, diharapkan nantinya modul yang dikembangkan dapat dijadikan salah satu sumber acuan bagi guru-guru di sekolah dalam melaksanakan pembelajaran multikultural dalam pembelajaran tematik di SD. Manfaat lainnya diharapkan melalui penggunaan modul dapat membantu peserta didik dalam menerima dan memahami pendidikan multikultural sekaligus menguatkan karakter cinta tanah air dan nasionalisme pada diri peserta didik.

\section{KAJIAN PUSTAKA Pendidikan Multikultural}

Menurut (Tenri, 2008) multikuralisme adalah sebuah kesadaran ilmiah baru atau ideologi yang memandang kesederajatan dalam perbedaan dan keragaman sebagai hal yang begitu penting dalam kehidupan bersama. Selanjutnya Hall (Rampersad, 2014) juga memaparkan bahwa multikultural adalah karakteristik sosial komunitas budaya yang berbeda dan tinggal bersama dan berusaha membangun kehidupan bersama serta mempertahankan identitas asli mereka.

Menurut Mughni (Miftah, 2016) menjelaskan bahwa pendidikan multikultural adalah pendidikan yang menghargai perbedaan. Dari definisi-definisi tersebut dapat diambil kesimpulan bahwa pendidikan multikulturalisme mengajarkan tentang menghargai semua peserta didik tanpa mendang latar belakang, jenis kelamin, kelas sosial, etnis, ras, agama, dan budayanya. Semua peserta didik memiliki kesempatan yang sama untuk belajar di sekolah.

Tujuan dari pendidikan multukuralisme ini dijelaskan oleh Klein (Banks, 2015) peserta didik dari berbagai kelompok ras, etnis, dan kelas sosial akan mengalami kualitas pendidikan serta memberi kesempatan kepada peserta didik laki-laki dan perempuan untuk mendapatkan kesuksesan dan mobilitas pendidikan.

\section{Karakter Cinta Tanah Air dan Nasionalisme}

Menurut Yuliatin (Erni, 2016) menjelaskan bahwa cinta tanah air adalah rasa bangga, rasa menghargai, rasa memiliki, rasa menghormati dan loyal pada negara tempat ia tinggal, hal ini tergambar dari perilakunya menjaga dan melindungi negaranya, rela berkorban demi kepentingan bangsa, serta turut melestarikan budaya-budaya yang ada di negara tersebut. Dari penjelasan diatas dapat diambil kesimpulan bahwa cinta tanah air tidak hanya rasa bangga tetapi juga dapat tercermin dari perilaku cinta tanah air dengan rela berkorban demi kepentingan bangsa dan negara.

Cinta tanah air adalah berupaya dengan sepenuh hati menerima tanah tumpah darah/negara kita sebagai bagian yang harus kita lindungi dan kita kembangkan (Rusyan, 2013). Rasa cinta tanah air dipahami sebagai suatu perasaan mencintai bangsa dengan sepenuh hati sehingga berusaha untuk melindungi dan memajukan kehidupan bangsanya agar dapat bersaing dengan bangsa lain.

Cinta tanah air adalah perasaan cinta terhadap bangsa dan negaranya sendiri. Usaha membela bangsa dari serangan penjajahan. Dalam cinta tanah air terdapat nilai-nilai kepahlawanan ialah: rela dengan sepenuh hati berkorban untuk bangsa dan negara. Rasa cinta tanah air adalah rasa kebanggaan, rasa memiliki, rasa menghargai,rasa menghormati dan loyalitas yang dimiliki oleh setiap individu pada negara tempat dimana ia tinggal, yang tercermin dari perilaku membela tanah airnya, menjaga dan melindungi tanah airnya, rela berkorban demi kepentingan bangsa dan negaranya, mencintai adat atau budaya yang ada di 
negaranya dengan melestarikannya dan melestarikan alam dan lingkungan (Ismawati \& Suryanto, 2015).

Atika (2014) dalam penelitiannya menjelaskan bahwa pelaksanaan pendidikan karakter cinta tanah air bisa dilakukan sebelum masuk kelas, proses pembelajaran, pulang sekolah, dan ekstrakurikuler yang diadakan di sekolah. Seperti mengajarkan nilai-nilai karakter cinta tanah air berbentuk melestarikan kebudayaan tradisional Indonesia dengan mengajarkan tari. Bertujuan agar anak bisa mengenal budaya Indonesia dan bisa melestarikannya. Pemberian atau penanaman nilai-nilai karakter cinta tanah air ini bukan hanya mengajarkan tarian tradisional saja, tapi juga dengan mengajarkan anak untuk belajar giat, mengajarkan berbahasa Indonesia dan memakai bahasa Indonesia ketika belajar, menyanyikan lagu-lagu wajib Indonesia. Penanaman nilai-nilai karakter cinta tanah air diatas dapat berupa menjaga kelastarian Indonesia dengan tidak membuang sampah sembarangan tempat yang mana bisa merusak lingkungan dan guru juga mengajarkan untuk menjaga kesimbangan alam dengan menanam pohon. Tapi sayangnya pelaksanaan upacara bendera yang seharusnya diajarkan guru tidak dilaksanakan dengan alasan peserta didik terlalu sedikit.

Menurut Kamus Besar Bahasa Indonesia (Saputri, 2016) bahwa nasionalisme adalah paham (ajaran) untuk mencintai bangsanya sendiri atau suatu kesadaran dari masing-masing anggota suatu bangsa yang secara konkret bersama-sama berjuang untuk mencapai, mempertahankan identitas, intregitas, potensi bangsa, serta memiliki semangat kebangsaan yang tinggi. Dari penjelasan tersebut dapat diambil poin penting bahwa nasionalisme merupakan ajaran untuk mencintai bangsa sendiri

Nasionalisme dipahami sebagai suatu loyalitas tertinggi terhadap bangsa, yang muncul karena adanya kesadaran identitas bersama meskipun yang berbeda dengan lainnya (Wahyudi, Eka;, 2015). Nasionalisme diartikan sebagai paham tentang kecintaan dan loyalitas yang tinggi terhadap bangsanya karena di dalam diri telah tertanam identitas yang sama.

\section{Pembelajaran Tematik}

Menurut (Fathurrochman, 2015) bahwa prinsip pembelajaran tematik integratif yaitu mengaitkan semua muatan pelajaran dalam suatu tema dengan memperhatikan pengembangan aspek kognitif, afektif, dan psikomotorik peserta didik sehingga dapat memberikan pembelajaran yang bermakna. Tema digunakan untuk mengaitkan beberapa mata pelajaran agar dapat mengembangkan peserta didik baik dari aspek afektif, kognitif dan psikomotorik. (Jhon, 2015) menambahkan bahwa tematik integratif merupakan rangkaian pelajaran yang mengintegrasikan mata pelajaran di seluruh kurikulum, seperti matematika, membaca, seni bahasa, studi sosial, sains, dan sebagainya, yang semuanya sesuai dengan tema utama di unit.

Dari pemaparan beberapa pendapat diatas dapat ditarik kesimpulan bahwa tematik integratif merupakan pembelajaran yang mengintegrasikan semua mata pelajaran dan menggunakan tema untuk mengaitkan beberapa mata pelajaran agar dapat mengembangkan peserta didik baik dari aspek afektif, kognitif dan psikomotorik agar dapat memberikan kesempatan kepada peserta didik untuk menghubungkan pengetahuan dan pengalaman yang dimiliki untuk menyelesaikan masalah.

\section{Modul}

Menurut Winkel (Susilo, Peserta didikndari, \& Bandi, 2016) menjelaskan bahwa pembelajaran adalah satuan program belajar mengajar yang terkecil, yang dipelajari oleh peserta didik sendiri secara perseorangan atau diajarkan oleh peserta didik kepada dirinya 
Pengembangan Modul Pendidikan Multikultural Berbasis Karakter Cinta Tanah Air dan Nasionalis pada Pembelajaran Tematik (Laila Fatmawati, Rani Dita Pratiwi, Vera Yuli Erviana)

sendiri self-instructional. Selanjutnya, Depdikbud (Susilo, Peserta didikndari, \& Bandi, 2016) memaparkan bahwa modul merupakan bahan ajar cetak yang dirancang untuk dapat dipelajari secara mandiri oleh peserta pembelajaran. Modul disebut juga media untuk belajar mandiri karena di dalamnya telah dilengkapi petunjuk untuk belajar sendiri. Berdasarkan pernyataan tersebut dapat disimpulkan bahwa modul pembelajaran merupakan bahan ajar cetak yang di dalamnya telah dirancang untuk peserta didik agar dapat belajar secara mandiri.

Modul juga memiliki beberapa karakteristik antara lain berbentuk unit pengajaran terkecil dan lengkap, berisi rangkaian kegiatan belajar yang dirancang secara sistematis, berisi tujuan belajar yang dirumuskan secara jelas dan khusus, memungkinkan peserta didik belajar mandiri, dan merupakan realisasi perbedaan individual serta perwujudan pengajaran individual (Pantiwati, 2016). Ada beberapa point dari pengertian di atas bahwa modul yang di rancang harus sistematis, serta dirumuskan secara jelas agar nantinya peserta didik dapat belajar secara mandiri.

\section{METODE PENELITIAN}

Berdasarkan masalah dan tujuan penelitiannya, penelitian ini merupakan penelitian dan pengembangan (Research and Development). Model pengembangan dalam penelitian pengembangan ini mengikuti desain dari (Borg, W,R; Gall, M,D;, 2007) dibatasi sampai pada tahap final product revision. Penelitian dilakukan dari bulan April sampai dengan Agustus 2017. Tempat penelitian SD Muhammadiyah Bodon, Jagalan, Banguntapan, Bantul, Daerah Istimewa Yogyakarta.

Peserta didik sebagai subjek penelitian yang menjadi bahan uji coba terbatas dan uji coba lapangan dari produk media yang telah dibuat oleh peneliti. Subjek uji coba terbatas dalam penelitian ini adalah peserta didik kelas II A dengan subjek uji coba 10 peserta didik. Sedangkan subjek uji lapangan dilaksanakan oleh seluruh peserta didik kelas II B dengan jumlah 35 peserta didik yang berasal dari SD Muhammadiyah Bodon, Yogyakarta. Teknik pemilihan subjek penelitian dengan teknik purposive sampling.

Penelitian ini mengembangkan modul pendidikan multikultural berbasis karakter cinta tanah air dan nasionalisme pada pembelajaran tematik-integratif. Prosedur pengembangan modul pendidikan multikultural yang akan dikembangkan dalam penelitian ini adalah: pertama, studi pendahuluan dan analisis kebutuhan. Langkah ini dilakukan untuk mendapatkan informasi sejauh mana pengembangan produk modul pendidikan multikultural ini dibutuhkan dalam pembelajaran dilakukan dengan cara analisis kurikulum pembelajaran tematik-integratif, analisis kebutuhan peserta didik, menyusun flow chart dan story board, serta telaah literatur. Kedua, perencanaan yang meliputi penentuan format modul, dan nilainilai karakter yang akan diintegrasikan. Ketiga, pengembangan produk modul dan penyusunan instrumen. Pada tahap ini produk awal sudah dikembangkan dan juga mengembangkan instumen penelitian yang meliputi lembar validasi untuk expert judgment. Keempat, validasi ahli yang terdiri dari 4 orang validator (ahli materi, ahli pembelajaran, ahli bahasa, dan ahli tampilan (kegrafikan), ahli instrumen melalui forum focus group discussion (FGD). Kelima, saran dari expert judgement saat FGD digunakan sebagai bahan untuk memperbaiki produk sesuai masukan dari para ahli maka dilakukan revisi I. Keenam, uji coba terbatas yaitu mengujikan produk kepada 10 orang peserta didik kelas 2 di SD Muhammadiyah Bodon. Ketujuh, saran dari guru dan repson dari peserta didik maka dilakukan revisi II dengan menganalisis hasil uji coba terbatas dan merevisi untuk menyusun produk utama. Kedelapan, uji coba lapangan yaitu mengujikan produk ke 35 orang peserta didik kelas II di SD Muhammadiyah Bodon. Uji coba lapangan dilakukan untuk mengetahui kelayakan modul pendidikan multikultural berdasarkan angket. Kesembilan, revisi III dilakukan karena masukan untuk perbaikan dari hasil uji lapangan berdasarkan hasil angket. Teknik pengumpulan data yang digunakan dalam penelitian ini adalah wawancara, observasi 
pembelajaran tematik, penilaian produk oleh para ahli, penilaian modul dari guru dan angket respon peserta didik. Sedangkan instrumen yang digunakan dalam pengumpulan data ini yaitu 1) pedoman wawancara untuk mendapatkan informasi awal mengenai analisis kebutuhan di SD; 2) lembar observasi pembelajaran tematik; 3) lembar penilaian produk yang berupa lembar penilaian oleh expert judgment dan masukan para pakar ketika FGD;4) lembar penilaian oleh guru saat uji coba terbatas dan uji coba lapangan; dan 5) angket respon peserta didik pada saat uji kelompok terbatas dan uji coba lapangan.

Teknik analisis data pada penelitian pengembangan ini ada dua yaitu teknik analisis kualitatif dan teknik analisis data kuantitatif. Penjelasan tentang kedua teknik analisis ini adalah sebagai berikut:

Teknik Analisis Data Kualitatif: Data kualitatif dalam penelitian ini berupa kritik dan saran untuk menyempurnakan produk dari pengembangan itu sendiri. Data kualitatif diperoleh dari uji validasi ahli media, ahli materi, ahli pembelajaran, dan uji coba produk.Teknik Analisis Data Kuantitatif: Data kuantitatif diperoleh dari uji validasi ahli media, ahli materi, ahli pembelajaran, respon peserta didik dan lembar penilaian guru. data kuantitatif berupa skor yang diperoleh dari angket yang telah disebar.

Perhitungan kelayakan modul pendidikan multikultural diketahui dengan menggunakan rumus kelayakan media pembelajaran skala empat pada tabel 1 menurut Mardhapi (2008) sebagai berikut:

Tabel 1.

Kategori Kelayakan Media

\begin{tabular}{|c|c|c|c|}
\hline & No & Skor & Kategori \\
\hline & 1 & $\mathrm{X} \geq \overline{\bar{X}}+1 . \mathrm{SB}_{\mathrm{x}}$ & Sangat Baik / Sangat Layak \\
\hline & & $\bar{X}+1 . \mathrm{SBx}>\mathrm{X} \geq \bar{X}$ & Baik / Layak \\
\hline & & $\bar{X}>\mathrm{X} \geq \bar{X}-1 . \mathrm{SB}_{\mathrm{x}}$ & Tidak Baik / Kurang Layak \\
\hline & 4 & $\mathrm{X}<\bar{X}-1 . \mathrm{SB}_{\mathrm{x}}$ & Sangat Tidak Baik / Tidak Layak \\
\hline \multicolumn{4}{|c|}{ Keterangan tabel: } \\
\hline $\bar{X}$ & \multicolumn{3}{|c|}{$=$ Rata-rata ideal $\frac{1}{2}\left(X_{\max }+X_{\min }\right)$} \\
\hline SBx & \multicolumn{3}{|c|}{$=$ Simpangan baku ideal $\frac{1}{6}\left(X_{\max }-X_{\min }\right)$} \\
\hline
\end{tabular}

Rumus kelayakan media di atas digunakan sebagai acuan penilaian kelayakan modul pendidikan multikultural, dengan adanya runus kelayakan media diatas maka akan diketahui kelayakan modul pendidikan multikultural untuk peserta didik kelas II sekolah dasar.

\section{HASIL PENELITIAN DAN PEMBAHASAN}

Penelitian ini dilaksanakan di SD Muhammadiyah Bodon dengan melibatkan 10 peserta didik kelas II A dan 35 peserta didik kelas II B. Proses pengembangan modul pendidikan multikultural berbasis nasionalisme dan cinta tanah air melalui berbagai tahapan. Paparan hasil penelitian berguna untuk menjawab pertanyaan penelitian tentang langkahlangkah pengembangan modul dan hasil kelayakan pengembangan modul. Langkah-langkah pengembangan modul mengikuti prosedur menurut Borg dan Gall yaitu:

1. Research and information collecting, pada langkah ini dilakukan studi pendahuluan pada peserta didik kelas II A SD Muhammadiyah Bodon sebagai analisis kebutuhan awal. Berdasarkan data yang terkumpul dari hasil observasi pembelajaran, wawancara dengan guru kelas dan peserta didik kelas II dapat disimpulkan bahwa pemahaman guru dan peserta didik tentang pendidikan multikultural masih kurang, dalam pengintegrasian dengan pembelajaran juga masih minin, belum tersedia mahan ajar yang berisi 
Pengembangan Modul Pendidikan Multikultural Berbasis Karakter Cinta Tanah Air dan Nasionalis pada Pembelajaran Tematik (Laila Fatmawati, Rani Dita Pratiwi, Vera Yuli Erviana)

pendidikan multikultural. Untuk itu diperlukan modul yang memudahkan guru dan peserta didik memahami esensi pendidikan multikultural sekaligus dapat dijadikan sebagai suplemen tambahan pembelajaran tematik karena selama ini bahan ajar hanya terbatas buku guru dan buku siswa serta buku pendamping. Selanjutnya dilakukan analisis kurikulum dengan mengkaji standar isi dalam buku guru dan buku siswa kelas II. Masing-masing jejaring tema yang mengaitkan beberapa KD dianalisis kemudian dicari KD dan indikator yang tepat diintegrasikan dengan pendidikan multikultural. Pengkajian standar isi ini dilakukan agar bahan ajar berbentuk modul yang dihasilkan sesuai dengan tujuan pembelajaran yang diharapkan. Studi kepustakaan juga dilakukan untuk mengkaji temuan penelitian sebelumnya. Penelitian terdahulu dari (Herimanto, Triyanto, \& Pelu, 2014), menunjukkan bahwa pembelajaran budi pekerti (karakter) berbasis multikultural telah berhasil dilaksanakan melalui proses pembelajaran, pembiasaan, dan keteladanan yang dilakukan oleh semua warga sekolah. Selain itu sikap sosial peserta didik juga dapat ditingkatkan dengan metode pembelajaran inovatif hal ini yang menjadi acuan kegiatan peserta didik di dalam modul yang dikembangkan harus memperhatikan aspek inovasi (Sriwindari, Yudana, \& Suhandana, 2013). Kemudian disusun flow chart dan story board modul.

2. Planning, selanjutnya dari permasalahan yang didapat dibuatlah rencana pengembangan modul berupa penentuan format modul, indikator nilai-nilai karakter cinta tanah air dan nasionalisme yang akan dijadikan acuan untuk membuat instrumen.

3. Develop preliminary form of product, pada tahap ini dilaksanakan penyusunan dan pembuatan modul. Adapun rancangan modul sebagai terdiri dari kata pengantar, petunjuk penggunaan modul, bagian- bagian modul, daftar isi, pendahuluan, KI, peta konsep pengelompokan KD, deskrepsi materi, langkah-langkah pembelajaran, materi pembelajaran, latihan soal, evaluasi, glosarium, daftar pustaka, daftar pustaka gambar, biodata penulis, kunci jawaban. Selain itu pembuatan modul disertai langkah-langkah pengembangan modul sesuai dengan langkah-langkah pengembangan modul Purwanto (2007) yaitu tahap perencanaan, persiapan rancangan modul (outline), memulai penulisan, tahap review dan revisi, finalisasi.

4. Preliminary field testing, Setelah modul selesai dikembangan selanjutnya adalah tahap validasi. Bahan ajar modul dinilai kelayakan oleh ahli media, ahli materi, ahli pembelajaran, dan ahli bahasa. Indikator yang dikembangkan dalam instrumen mengacu pada indikator Depdiknas (2008) dan Arsyad (2016).

Untuk mendapatkan penilaian dari para ahli, guru dan jawaban angket respon peserta didik dilakukan kategorisasi kelayakan melibatkan empat validator yaitu validasi media, validasi materi, validasi pembelajaran, dan validasi bahasa. Penilaian oleh guru dilakukan atas uji coba produk terbatas dan uji coba lapangan, sama halnya dengan respon peserta didik dilaksanakan pada uji coba terbatas dan uji coba lapangan. Selanjutnya dilakukan kategorisasi menggunakan rumus kelayakan dan kategorisasi dari Mardhapi (2008) sebagai berikut.

Tabel 2.

Kategorisasi Kelayakan

\begin{tabular}{lc}
\hline \multicolumn{1}{c}{ Skor } & Kategori \\
\hline$X \geq 60$ & Sangat Baik / Sangat Layak \\
$60>X \geq 50$ & Baik / Layak \\
$50>X \geq 40$ & Tidak Baik / Kurang Layak \\
$X<40$ & Sangat Tidak Baik / Tidak Layak \\
\hline
\end{tabular}


Kategorisasi dilakukan pada setiap penilaian yaitu saat validasi ahli, penilaian guru, dan hasil respon peserta didik. Perolehan hasil penilaian dan kategorisasi ditunjukkan pada tabel 3 sebagai berikut.

Tabel 3.

Hasil Penilaian dan Kategorisasi

\begin{tabular}{lcc}
\hline \multicolumn{1}{c}{ Penilaian } & Skor & Kategori \\
\hline Ahli Media & 66 & Sangat Baik \\
Ahli Materi & 72 & Sangat Baik \\
Ahli Pembelajaran & 74 & Sangat Baik \\
Ahli Bahasa & 60 & Sangat Baik \\
\hline
\end{tabular}

5. Main product revision, pada tahap ini merevisi produk awal yang sudah dikembangkan sesuai masukan dari para ahli saat FGD. Hasil validasi oleh para ahli saat FGD dinyatakan masuk kategori sangat baik. Namun, terdapat beberapa masukan untuk direvisi agar modul yang dikembangkan menjadi lebih sempurna Ahli media memberikan masukan agar desain peta konsep kompetensi dasar dan indikator lebih dipertegas, diberi contoh pengerjaan soal latihan terlebih dahulu sebelum masuk ke soal latihan, petunjuk penggunaan modul diperinci lagi mengingat salah satu sifat modul yaitu harus dapat dijadikan sebagai bahan belajar mandiri (Parmin \& Peniati, 2012). Perbaikan sesuai masukan dari pakar materi ditunjukkan pada gambar 1 dan 2.

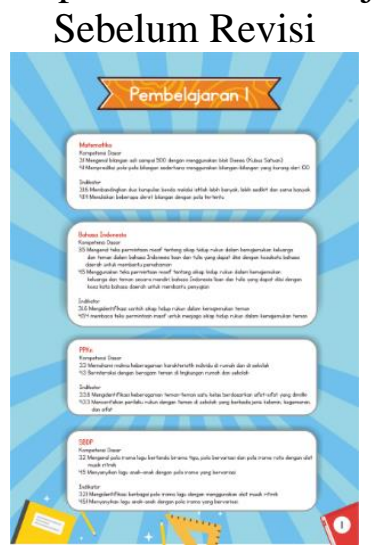

\section{Gambar 1.}

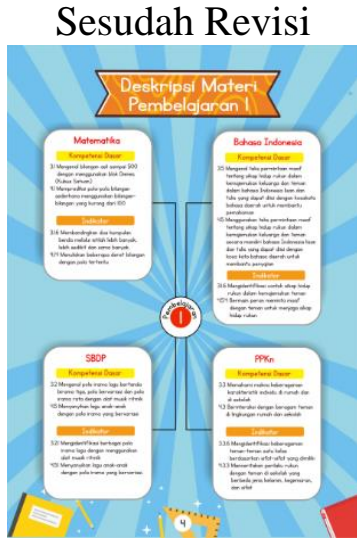

\section{Desain Peta Konsep Kompetensi Dasar dan Indikator}

Pada gambar 2 menunjukan perubahan desain yang sebelumnya tidak ada contoh pengerjaan soal maka di tambahkan cara pengerjaan soal.
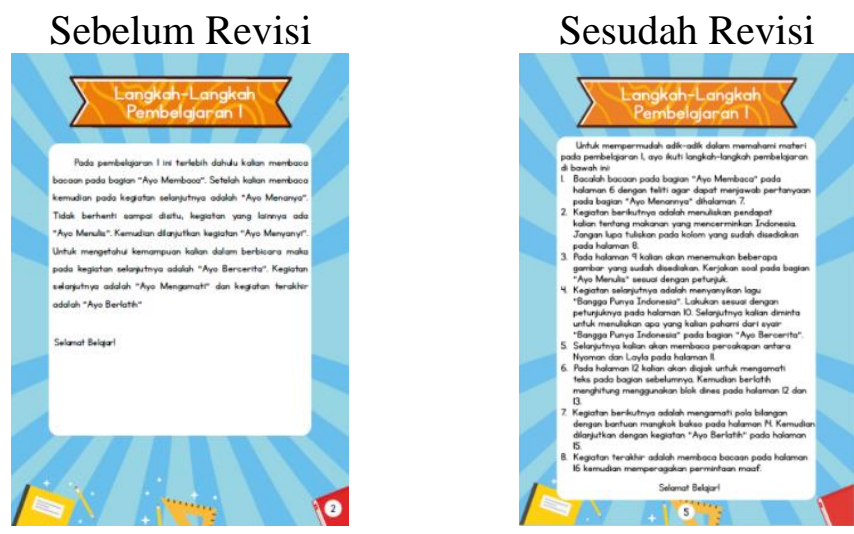

Gambar 2.

Petunjuk Penggunaan Modul 
Ahli materi memberikan masukan agar semua materi fokus untuk mengembangkan karakter cinta tanah air dan nasionalisme. Gambar 3 menunjukan adanya perubahan materi. Sebelumnya revisi materi tentang nasionalisme dan cinta tanah air belum terlalu nampak jelas. Setelah revisi penjelasan tentang nasionalisme dan cinta tanah air ditambahkan pada kesimpulan paragraf.

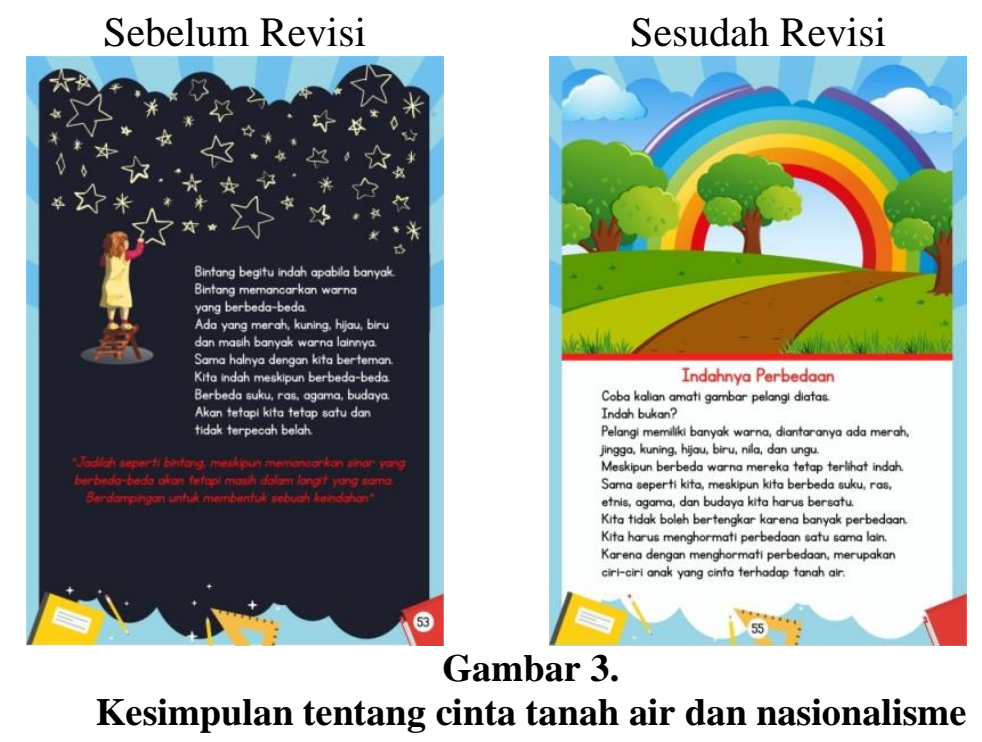

Ahli pembelajaran memberikan masukan agar keterkaitan antar mata pelajaran dalam tema perlu ditegaskan agar kesan tematik integratif menjadi lebih kentara. Sedangkan masukan dari ahli bahasa yaitu meminimalisir kata-kata yang bermakna ambigu agar tidak terjadi multitafsir.

6. Main field testing, pada tahap ini biasanya disebut uji coba produk terbatas. Uji coba dilaksanakan dengan 10 peserta didik di kelas II A SD Muhammadiyah Bodon. Hasil penelitian uji coba produk terbatas memperoleh skor 375 termasuk kategori "sangat baik" kemudian di rata-rata memperoleh skor 37,5 karena $X \geq 30$. Sedangkan guru memberikan skor 70 termasuk kategori "sangat baik" karena $X \geq 60$ yaitu 70 .

7. Operational product revision, pada tahap ini perbaikan dilakukan atas apa yang sudah dilaksanakan ditahap sebelumnya. Revisi dilakukan untuk mendapatkan hasil yang diinginkan.

8. Operational Field Testing, pada tahap ini uji coba lapangan mulai dilaksanakan. Subjek dari uji coba adalah peserta didik kelas II B dengan jumlah peserta didik 35 peserta didik. Hasil penelitian uji coba lapangan memperoleh skor 1293 termasuk kategori "sangat baik" kemudian di rata-rata memperoleh skor 36,94 karena $X \geq 30$. Sedangkan guru memberikan skor 76 termasuk kategori "sangat baik" karena $X \geq 60$ yaitu 76

9. Final Product Revision, tahap yang terakhir adalah revisi akhir produk disempurnakan sesuai dengan saran dan masukan dari guru, serta hasil angket respon peserta didik.

\section{Pembahasan}

Secara garis besar hasil dari penilaian modul pendidikan multikultural dapat disimpulkan bahwa pengembangan modul pendidikan multikultural memiliki kategori "Sangat Baik" oleh karena itu modul pendidikan multikultural dikatakan layak sebagai bahan ajar tambahan baik untuk dipelajari secara individu maupun dengan kelompok terbimbing. Pada hakikatnya suatu modul memiliki beberapa karakteristik antara lain self intruction yaitu membantu peserta didik untuk belajar secara mandiri, self contained mencakup materi yang 
diperlukan dalam pembelajaran, stand alone tidak bergantung pada bahan ajar atau media lainnya, adaptif dengan perkembangan iptek, use friendly terkait penggunaan bahasa yang mudah dipahami peserta didik (Arum, Wahyudi. 2016) .

Pembelajaran menggunakan modul memiliki beberapa kelebihan (Lasmiyati, Harta. 2014) yaitu: (a) modul dapat memberikan umpan balik sehingga pebelajar mengetahui kekurangan mereka dan segera melakukan perbaikan, (b) dalam modul ditetapkan tujuan pembelajaran yang jelas sehingga kinerja peserta didik belajar terarah dalam mencapai tujuan pembelajaran, (c) modul yang didesain menarik, mudah untuk dipelajari, dan dapat menjawab kebutuhan tentu akan menimbulkan motivasi peserta didik untuk belajar, (d) modul bersifat fleksibel karena materi modul dapat dipelajari oleh peserta didik dengan cara dan kecepatan yang berbeda, (e) kerjasama dapat terjalin karena dengan modul persaingan dapat diminimalisir dan antara pebelajar dan pembelajar, dan (f) remidi dapat dilakukan karena modul memberikan kesempatan yang cukup bagi peserta didik untuk dapat menemukan sendiri kelemahannya berdasarkan evaluasi yang diberikan.

Pengembangan modul yang dilakukan disesuaikan dengan pendapat Depdiknas (Lubis dkk, 2015), modul berisi paling tidak tentang (1) petunjuk belajar (petunjuk peserta didik/guru); (2) kompetensi yang akan dicapai; (3) content atau isi materi; (4) informasi pendukung; (5) latihan-latihan; (6) petunjuk kerja, dapat berupa Lembar Kerja (LK); (7) evaluasi; dan (8) balikan terhadap hasil evaluasi. Adapun rancangan modul yang dikembangkan meliputi (1) kata pengantar; (2) petunjuk penggunaan modul; (3) bagianbagian modul; (4) daftar isi; (5) pendahuluan; (6) KI; (7) peta konsep pengelompokan KD; (8) deskrepsi materi; (9) langkah-langkah pembelajaran; (10) materi pembelajaran; (11) latihan soal; (12) evaluasi; (13) glosarium; (14) daftar pustaka; (15) daftar pustaka gambar; (16) biodata penulis; (17) kunci jawaban.

\section{SIMPULAN DAN SARAN}

Berdasarkan hasil penelitian dan pengembangan modul pendidikan multikultural berbasis nasionalisme dan cinta tanah air yang telah dilaksanakan dapat disimpulkan bahwa langkah-langkah yang digunakan dalam penyusunan modul ialah: (a) Tahap perencanaan, pada tahap ini peneliti melaksanakan analisis kurikulum, mempersiapkan materi yang sesuai dengan tema yang diambil, serta memikirkan urutan penyajian materi dalam modul. (b) Persiapan rancangan modul (outline), pada tahap ini peneliti mempersiapkan outline penulisan diantaranya adalah: kata pengantar, petunjuk penggunaan modul, bagian-bagian modul, daftar isi, pendahuluan, KI, peta konsep pengelompokan $\mathrm{KD}$, deskrepsi materi, langkah-langkah pembelajaran, materi pembelajaran, latihan soal, evaluasi, glosarium, daftar pustaka, daftar pustaka gambar, biodata penulis, kunci jawaban. (c) Memulai penulisan, pada tahap ini penulis memulai menulis modul sesuai dengan rancangan yang sudah di tetapkan sebelumnya. Selain itu pada tahap penulisan juga memperhatikan tentang penggunaan bahasa yang jelasa, memberikan contoh-contoh dalam modul, dan menampilkan gambar agar materi dapat lebih kongkret. (d) Tahap Review dan Revisi, pada tahap ini modul di review oleh ahli media, ahli materi, ahli pembelajaran, ahli bahasa, guru kelas, dan peserta didik. Setelah itu diuji cobakan pada kelompok

Modul pendidikan multikultural berbasis karakter cinta tanah air dan toleransi yang elah dikembangkan layak untuk digunakan. Kelayakan dinilai dari hasil validasi oleh ahli media memperoleh skor 66 dengan kategori "Sangat Baik", ahli materi memperoleh skor 72 dengan kategori "Sangat Baik", ahli pembelajaran memperoleh skor 74 dengan kategori "Sangat Baik", dan ahli bahasa memperoleh skor 60 dengan kategori "Sangat Baik" . Pengembangan modul pendidikan multikultural mendapatkan respon positif dari guru dan peserta didik, hal tersebut ditunjukan dari penilaian guru dan lembar respon peserta didik pada saat uji coba produk terbatas lembar respon peserta didik diisi oleh 10 peserta didik dari 
Pengembangan Modul Pendidikan Multikultural Berbasis Karakter Cinta Tanah Air dan Nasionalis pada Pembelajaran Tematik (Laila Fatmawati, Rani Dita Pratiwi, Vera Yuli Erviana)

kelas 2A. Mendapatkan skor 375 dengan nilai rata-rata 37,5 dan termasauk dalam kategori nilai sangat baik. sedangkan lembar penilaian guru mendapatkan skor 70 yang juga memiliki kategori nilai "Sangat Baik". Pada saat uji coba lapangan lembar respon peserta didik diisi oleh 35 peserta didik dari kelas 2B. Mendapatkan skor 1293 dengan nilai rata-rata 36,94 dan termasuk kategori "Sangat Baik". sedangkan lembar penilaian guru mendapatkan skor 76 yang juga memiliki kategori "Sangat Baik".

Bagi guru, modul pendidikan multikultural yang telah dikembangkan dapat digunakan sebagai alat bantu dalam mengenalkan sikap multikultural, nasional, dan cinta tanah air pada peserta didiknya. Sedangkan bagi peserta didik, modul pendidikan multikultural merupakan salah satu media pembelajaran bagi peserta didik yang dapat digunakan sebagai alternatif belajar peserta didik disekolah maupun belajar mandiri di rumah.

\section{UCAPAN TERIMA KASIH}

Artikel publikasi ini merupakan hasil dari penelitian dosen pemula yang didanai oleh Direktorat Riset dan Pengabdian Kepada Masyarakat, Kemeterian Riset, Teknologi, dan Pendidikan Tinggi Republik Indonesia. Konten artikel ini merupakan sebagian dari penelitian Pengembangan Modul Pendidikan Multikultural Berbasis Karakter Keindonesiaan pada Pembelajaran Tematik Integratif.

\section{DAFTAR PUSTAKA}

Arsyad, A. 2016. Media Pembelajaran. Jakarta: PT. Raja Grafindo Persada.

Arum, T.S; Wahyudi. 2016. Pengembangan modul pembelajaran tematik integratif subtema hubungan makhluk hidup dalam ekosistem pendekatan saintifik untuk kelas 5 SD. Jurnal Scholaria. 6 (3). 239-250.

Atika, S. (2014). Pelaksanaan pendidikan karakter (religius, cinta tanah air dan disiplin) di SLB Al Ishlaah Padang. Padang: E-Jupekhu. 3 (3), 750-751.

Banks, J. A. (2015). Cultural Diversity And Education Foundation, Curriculum and Teaching. Washington: University Of Washington.

Borg, W,R; Gall, M,D;. (2007). Educational research an introduction. New York: Longman.

Depdiknas. 2008. Panduan pengembangan bahan ajar. Direktoral Jendral Manajemen Pendidikan Dasar dan Menengah: Direktorat Pembinaan Sekolah Menengah Atas.

Erni, M. (2016). Internalisasi Nilai-Nilai Pancasila dan Rasa Cinta Tanah Air pada Remaja di Perbatasan Indonesia-Malaysia. PSIKOBORNEO, 4 (4), 849-856.

Fathurrochman. (2015). Pengembangan model pembelajaran tematik integratif eksternal dan internal di madrasah ibtidaiyah. Jurnal Penelitian Sosial Keagamaan, 9 (1), 329-350.

Hanum, F; Raharja, S. (2013). Pengembangan model pembelajaran multikultural terintegrasi mata pelajaran IPS di Sekolah Dasar. Jurnal Penelitian Ilmu Pendidikan, 2 (2), 39-51.

Herimanto, Triyanto, \& Pelu, M. (2014). Pengembangan model pembelajaran budi pekerti berbasis multikultural. JISPINDO, 1 (1), 79-100.

Ismawati, Y. T., \& Suryanto, T. (2015). Peran guru PKn dalam membentuk sikap cinta tanah air di SMA Negeri Mojosari Kabupaten Mojokerto. Kajian Moral dan Kewarganegaraan, 2 (3), 883-887. 
Jhon, Y. J. (2015). A "New" Thematic, Integrated Curriculum for Primary Schools of Trinidad and Tobago: A Paradigm Shift. International Journal of Higher Education, 4 (3) , 172-187.

Kompasiana. (2015). Pendidikan Indonesia Ditengah Multikultural Budaya dalam Menyongsong Era Globalisasi Dunia. http://www.kompasiana.com /_berproces123/indonesia-di-tengah-multikultural-budaya-dalam-menyongsong-era-globalisasidunia_55b4ce30959373d90690a442

Lasmiyati; Harta, I. (2014). Pengembangan Modul Pembelajaran untuk Meningkatkan Pemahaman Konsep dan Minat SMP. Surakarta: Jurnal Pendidikan Matematika. 9 (2), 163.

Lubis, Syanti,M. (2015). Pengembangan Modul Pembelajaran Bahasa Indonesia Berbantuan Peta Pikiran Pada Materi Menulis Makalah Peserta didik Kelas XI SMA/MA. Padang: Jurnal Bahasa, Sastra dan Pembelajaran. 2 (1), 19.

Mardapi, D. (2008). Teknik Penyusunan Instrumen Tes dan Nontes. Yogyakarta: Mitra Cendikia Press.

Miftah, M. (2016). Multicultural Education In The Diversity Of National Cultures. Qudus International Journal of Islamic Studies, 4 (2), 167-185.

Na'im dan Syahputra, H. (2010). Kewarganegaraan, Suku Bangsa, Agama, dan Bahasa Sehari-Hari Penduduk Indonesia Hasil Sensus Penduduk 2010. Jakarta: Badan Pusat Statistik.

Pantiwati, Y. (2016). Pengembangan Modul Evaluasi Pembelajaran dengan Model Pembelajaran 7E Berbasis Kreatifitas. Proceeding Biology Education Conference, 13 (1), 461-467.

Parmin; Peniati, E. (2012). Pengembangan modul mata kuliah strategi belajar mengajar IPA berbasis hasil penelitian. Jurnal Pendidikan IPA Indonesia. 1 (1). 8-15.

Purwanto,dkk. (2007). Pengembangan Modul. Jakarta: Departemen Pendidikan Nasional Pusat Teknologi Informasi dan Komunikasi Pendidikan.

Rampersad, I. (2014). Multiculturalism and the Challenge of Managing Diversity in Trinidad and Tobago. Journal of Social Science for Policy Implications, 2 (1), 127-149.

Rusyan, T;. (2013). Membangun disiplin karakter anak bangsa. Jakarta: PT Pustaka Dinamika.

Saputri. (2016). Peran dosen dalam menumbuhkan jiwa nasionalisme mahasiswa program studi PPKn IKIP PGRI Bojonegoro. Jurnal Media Prestasi, 17(1), 41-50.

Sriwindari; Yudana; Suhandana. (2013). Pengaruh implementasi pembelajaran Teknik Klarifikasi Nilai (TKN) berbasis multikultural terhadap sikap sosial dan Prestasi Belajar PKn. Jurnal Penelitian Pascasarjana Universitas Pendidikan Ganesha, 4 (1).

Sumarno, S. (2010). Evaluasi program keserasian sosial dalam penanganan konflik sosial. Retrieved from httppuslit.kemsos.go.iduploadpostfilesa047fc7729b61b11e5d298433d00b4de.pdf diakses pada tanggal 20 April 2016 pukul 17:15 WIB

Susilo, A., Peserta didikndari, \& Bandi. (2016). Pengembangan Modul Berbasis Pembelajaran Saintifik untuk Peningkatan Kemampuan Mencipta Peserta didik dalam Proses Pembelajaran Akutansi Peserta didik Kelas XII SMA N 1 Slogohimo. Jurnal Pendidikan Ilmu Sosial, 26 (1), 50-56. 
Pengembangan Modul Pendidikan Multikultural Berbasis Karakter Cinta Tanah Air dan Nasionalis pada Pembelajaran Tematik (Laila Fatmawati, Rani Dita Pratiwi, Vera Yuli Erviana)

Tafsir. 2015. Pendidikan Multikultural Suatu Upaya Penguatan Jati Diri Bangsa. Bandung: Pustaka Setia.

Tenri, A. (2008). Multikulturalisme dan Pendidikan Multikultural. Jurnal Penelitian, Gagasan, Sosiologi, dan Pengajaran, 1 (2), 84-98.

UU Sistem Pendidikan Nasional. (2011). Undang-Undang Sistem Pendidikan Nasional Tahun 2003. Yogyakarta: Pustaka Pelajar.

Wahyudi, Eka, W;. (2015). Internalisasi nasionalisme melalui pendidikan Islam:analisis pemikiran KH Saifuddin Zuhri. Jurnal AKADEMIKA, 9(1), 119-136. 